\title{
The Influence of Growth Opportunities on IPO Initial Aftermarket Performance
}

\author{
Norliza Che-Yahya ${ }^{1} \&$ Siti Suhaila Abdul-Rahman ${ }^{1}$ \\ ${ }^{1}$ Faculty of Business and Management, Puncak Alam Campus, Universiti Teknologi MARA, Selangor, Malaysia \\ Correspondence: Norliza Che-Yahya, Faculty of Business and Management, Puncak Alam Campus, Universiti \\ Teknologi MARA, 42300 Bandar Puncak Alam, Selangor, Malaysia. Tel: 60-3258-7077.
}

Received: July 28, 2020

doi:10.5430/ijfr.v12n1p40
Accepted: September 29, 2020

Online Published: December 24, 2020

URL: https://doi.org/10.5430/ijfr.v12n1p40

\begin{abstract}
This study examined the influence of growth opportunities of firms on the immediate aftermarket performance of IPOs. The growth opportunities were defined as the amount of proceeds received during IPOs to activities that support the growth of a firm, such as assets acquisition, and research and development (R\&D). Acknowledging that not much information about a firm is possibly received by investors prior to its listing in a stock exchange, investors will rely mostly on the information supplied in the "Prospectus" as a reliable channel of their participation evaluation in the IPO firm. One crucial piece of information is on the allocation amount of IPO proceeds as it should signal the directions of a firm in the aftermarket. This study proposes that an IPO firm would have a larger potential to grow if it allocates a bigger amount of proceeds to growth activities, which will encourage higher demand on and subscription of shares of the IPO firm. Eventually, the higher demand would lead to a higher share price of the firm and a higher return for investors in the aftermarket. Leveraging this proposition, a total sample of 436 IPOs listed on Bursa Malaysia from 2000 to 2017 were tested using the multiple regression analysis. This study reveals that the amount of proceeds allocated to growth activities are positively and significantly related to the return of IPOs in the initial aftermarket.
\end{abstract}

Keywords: growth opportunities, initial public offerings, initial return, aftermarket, use of proceeds

\section{Introduction}

One of the main goals of a firm is to maximize profits for continuous growth. This goal can be materialized only when the firm is fully supported by a desirable amount of capital. One way for a firm, particularly a privately listed firm, to acquire enough amount of capital is by going public. Mohd-Rashid, Abdul-Rahim, and Yong (2014) agree that a firm will have access to the capital market and an opportunity to increase its value through the issuance and selling of shares to public for the first time. The decision of a firm to go public for the first time is signified as the decision to issue initial public offerings (IPOs). IPOs are a popular decision of firms to obtain funds as it provides a firm an access to numerous investors (both institutional and retail investors). The investors will buy shares of a firm if they believe that the shares are worth enough for their investment. Thus, the intention of a firm to acquire funds will be fulfilled. Meanwhile, IPOs are seen as a suitable way to evade interest expenses, particularly if a firm opts for loans from banks. Hence, the issuance of IPOs is suggested as one of the important steps and strategic financing decisions by a firm (Luo, Qian, \& Ren, 2015).

Although IPOs are seen as an important step in a firm's life cycle, the listing of a firm in a stock exchange and the issuance of shares to public for the first time are not always pleasing. Apart from the major changes in the ownership structure, corporate governance, and financial reporting practices, which may not be welcomed by some of the existing shareholders, an IPO firm will also be threatened by the possibilities of its newly issued shares not to be entirely demanded (Aharony, Lee, \& Wong, 2000; Burton, Helliar, \& Power, 2004; Hung, Wong, \& Zhang, 2012; Lee, 2001; Teoh, Welch, \& Wong, 1998). Implicitly, the firm will not only be denied the chance to acquire the needed amount of funds, but will also experience a lower initial market price as well as negative initial aftermarket performance if its shares are under demanded. It is crucial for IPO firms to produce a good initial aftermarket performance as it will usually give an early indication on their potential sustainability and growth in the long term. As posited by Espenlaub, Khurshed, and Mohamed (2012), the longer period a firm could sustain its position in the IPO aftermarket, the better the chance that the firm will have to obtain continuous funds from investors to capitalize 
for profitable future projects. From the view of the investors, they will also be more likely to participate in IPOs with regards to firms with high sustainability prospects as the higher growth that IPO firms have could also indicate the growth in their wealth due to the increment in investment value (i.e., increment in price of their shares).

To date, numerous determinants to the IPO performance in the aftermarket have been studied. However, studies on the examination on growth opportunities of firms as the main explanatory determinant of the IPO performance are rather limited. The lack of examination given to growth opportunities of firms is somehow paradoxical considering the fact that investors, especially with a long-term investment goal, will be more attracted to a firm's capability to survive and grow over the long term as it will also signify an increment in their wealth during the long investment horizons (Espenlaub et al., 2012). Therefore, this study stands with a point to posit that an IPO firm will produce a good aftermarket performance due to a high demand on its shares from investors if it can offer reasonable growth abilities. It is now a duty of investors to deliberately gauge the growth prospect of a firm before they execute any investment decision. Certainly, a crucial area of discussion among investors should be centered on an avenue or a place for them to retrieve information on firm's growth prospects.

Based on Tajuddin, Abdullah, and Taufil-Mohd (2016), firms which went public are motivated primarily by several financial needs. The financial needs could be in the forms of liquidity purposes, debts obligations, capital expenditure, and R\&D. Once a firm has decided to go public for the first time, the firm is required by the Securities Commission to disclose all activities and the avenue where proceeds from the sale of its newly issued shares are expected to be channeled, in its advertising report or officially regarded as "Prospectus" (Amor \& Kooli, 2017; Andriansyah \& Messinis, 2016; Leone, Rock, \& Vasvari, 2007; Tajuddin et al., 2016). The proceeds from IPOs could be allocated to several activities, such as growth activities comprising of allocations to working capital, R\&D, and capital expenditures (Abdul Rahim \& Che Embi, 2013; Andriansyah \& Messinis, 2016; Tajuddin et al., 2016; Wyatt, 2014), secondary shares activities (Andriansyah \& Messinis, 2016), investment activities, which include assets acquisition, $\mathrm{R} \& \mathrm{D}$, and capital expenditures, liabilities activities, which are the repayment of existing and future debts (Andriansyah \& Messinis, 2016; Autore, Bray, \& Peterson, 2009; Leone et al., 2007; Wyatt, 2014), marketing activities, which include the activities on sales and advertisement (Amor \& Kooli, 2017; Leone et al., 2007), and for general corporate purposes (Amor \& Kooli, 2017).

This study proposes that the "intended use of proceeds" from the shares should transmit information about an issuer, which later influences an investor's decision and a firm's performance in the aftermarket. Leveraging the scope, this study intended to investigate the influence of firm's growth opportunities on its performance in the immediate aftermarket. Growth opportunities can be defined as the distribution of proceeds from IPOs to activities, which can help the sustainability of a firm (Abdul-Rahim \& Che-Embi, 2013; Tajuddin et al., 2016). In addition, Subrahmanyam and Titman (1999) define growth financing as the use of proceeds for the acquisition of fixed assets. The study suggests that the acquisition of new equipment is likely to lift up the production of a firm such that it would expand its market share. Andriansyah and Messinis (2016) similarly propose that the intended use of proceeds to purchase fixed assets will result in a positive post-IPO performance. Acknowledging both definitions in Subrahmanyam and Titman (1999) and Andriansyah and Messinis (2016), Tajuddin et al. (2016) summarize that the growth opportunities that an IPO firm could offer should be related to its ability in increasing stably its market share and the share price in the future.

Following the definitions of growth opportunities used in past studies, this study hypothesized that the higher the amount of proceeds are allocated to growth and investment activities, the higher the growth opportunities of firms. As supported by Amor and Kooli (2017), the investors will respond favorably if an IPO firm states 'investment' as the main venue where the proceeds will be channeled to. The favorable action from the market will later be translated into a positive immediate aftermarket performance. However, this theoretical relationship will remain to be vague if no study is initiated to confirm it, empirically. Thus, this study was conducted to provide empirical evidence on the influence of growth opportunities on firms' performance in the immediate aftermarket.

The rest of this paper is organized in several sections. Section 2 presents the literature review and Section 3 describes the data of this study and methodology. Section 4 discusses the empirical results, while Section 5 concludes the findings.

\section{Literature Review}

\subsection{Agency Theory, Growth Opportunities, and IPO Performance}

This study posits that the influence of growth opportunities on the performance of IPOs can be explained by the propositions and arguments built in the agency theory. The agency theory, developed by Jensen and Meckling (1976), 
proposes the detachment of ownership and control of resources (the principal-agent problem) as a prominent issue in a firm. The issue arises when the agent (manager) acts separately (for his own benefits) from the principal (owner). From the corporations' point of view, Morris (1987) contends that agency conflict occurs when the insiders (manager) are reluctant to participate in projects expected to be profitable to the outsiders (shareholders). To an extent, it is unfavorable for a manager to invest in any risky project if the failure will jeopardize his position in the firm, despite the perception of shareholders that all successful risky investments will appreciate the wealth of existing shareholders and value of the firms. In the context of this study, the agency conflict was hypothesized to arise when the principals (existing shareholders or potential investors) and agents (IPO issuers) have different motives and expectations on the firm's decision to go for public. To be specific, the main concern of investors when investing in a firm is the returns that they will earn. The investors expect to gain a high dividend or capital appreciation from their investment. This study posited that the investors can secure good returns only when a firm decides to allocate a higher amount of the IPO proceeds to activities, which can support the growth of the firms. However, not all firms that have gone public prioritize the proceeds to those activities. Some firms will allocate the proceeds mostly for debts repayment or other general expenses, which are not really consistent to the wishes of shareholders as it could be only to the advantage of the firm and managers. Therefore, this study proposes that the interest of shareholders and managers are aligned and the agency conflict is minimized only if firms allocate a higher portion of the IPO proceeds to growth activities. This proposition can be supported, particularly if the returns of the firm's shares are higher in the initial aftermarket due to the perception that investors are optimistic about putting their cash in the firm, this will motivate them to demand and subscribe for the firm's shares.

\subsection{Signaling Theory, Growth Opportunities, and IPO Performance}

The influence of growth opportunities of firms on performance in the immediate aftermarket can also be explained using the signaling theory. Signaling theory, proposed by Ross (1977), was derived from the information asymmetry hypothesis. The hypothesis proposes that investors (outsiders) do not receive a fair and similar information about the firms as compared to what the managers or firms (insiders) may receive (Engelen \& Van Essen, 2010; Ibbotson \& Ritter, 1995). Carey, Fang, and Zhang (2016) argue that the firms (IPO issuers) will have difficulty in communicating their ability and expectation to potential investors due to information asymmetry. As such, signaling tools will be used by firms to communicate to investors. That is, the potential investors would interpret any relevant published information transmitted by firms to understand the reasons behind any decision as well as for them to execute their investment decision. In the context of this study, it was proposed that IPO issuers can signal, for instance actual present and future value, and the quality of their firms, through information published in the prospectus. Specifically, this study posited that the information on "the intended use of proceeds" from IPOs could be utilized by IPO firms as a signaling tool to transmit information on the possible extent of success of the firms, both in the immediate and long-term aftermarket. Hence, this study posited that a firm that distributes higher amounts of IPO proceeds to growth and investment activities will highly encourage investors to invest in the firm due to the perception that the firm's priorities are growth and expansion. That is, the investors will interpret information on the "distribution of proceeds to growth activities" as a good signal. This proposition is consistent with Abdul-Rahim and Che-Embi's (2013) that high amount of proceeds allocated to growth activities is able to signal to investors the good future performance of the IPO firms.

\section{Data and Methodology}

The current study used all IPOs listed on the Main Market and ACE Market of Bursa Malaysia from the period of January 2000 to December 2017. A total of 566 IPOs had been issued within the coverage period. January 2000 was selected as the starting period of this study to allow the stock market to fully recover from any noise inherited from the 1997/1998 Asian financial crisis. This study ended the sample period in December 2017 as that was the latest year this study could cover, in order to avoid the surrounding negativities due to the election and external factors, such as trade wars and interest rate hikes by the US Federal Reserve, which also affected the Malaysian market to be unfavorable. A total of 436 IPOs were chosen to be in the final sample of the present study after excluding all rare types of IPOs, such as restricted offer for sale, restricted public issue, warrants, tender offer, financial, insurance, REITs firms, and IPO with a missing value and an outlier. All IPOs listed on the LEAP Market of Bursa Malaysia as the IPOs can only be subscribed by sophisticated investors were also excluded. The exclusion of rare types of IPO was due to the small number of issuance, which would lead to less meaningful results. Due to the different format of the financial statements presentation, this study excluded the financial, insurance, and REITs firms (Chordia, Roll, \& Subrahmanyam, 2001; Yatim, 2008). The sources of the data were mainly from the firm's prospectuses. The sources include the Bursa Malaysia website, Thomson Reuters Eikon database, and Bloomberg. 


\subsection{Definition and Measurement}

\subsubsection{Dependent Variable}

The dependent variable of the current study is initial aftermarket returns $\left(\mathrm{R}_{\mathrm{ia}}\right)$, which was measured as the percentage change in price on the first trading day (Anderloni \& Tanda, 2017; Mohd-Rashid et al., 2014). The measurement of $\mathrm{R}_{\mathrm{ia}}$ is as follows:

$$
R_{\text {ia }}=\frac{\text { Pclose }- \text { Poffer }}{\text { Poffer }} \times 100
$$

where, Pclose is the closing price on the first trading day of ith firms and Poffer is the offer price of ith firms.

\subsubsection{Main Independent Variable}

Growth opportunity of firms (GOPP), the main independent variable of this study, was defined as the distribution of proceeds received from investors to activities, such as R\&D, investment, and capital expenditure. The GOPP was measured as the total allocation of proceeds for growth and investment activities against the total proceeds from the issuance of IPOs through a public issue (Abdul-Rahim \& Che-Embi, 2013; Tajuddin et al., 2016). The measurement is as follows:

$$
\text { GOPP }=\frac{\text { Growth }}{\text { Proceeds }} \times 100
$$

where Growth is the number of proceeds allocated to growth and investment activities (e.g., fixed asset acquisition, capital expenditure, working capital) and Proceeds is the total proceeds from the issuance of a public issue.

\subsubsection{Other Independent Variables}

The summary list of the other independent variables of this study, expected sign, and supporting literature on the selection and prediction of signs of each variable are displayed in Table 1.

\begin{tabular}{|c|c|c|c|c|}
\hline No. & Variables & Measurement & $\begin{array}{l}\text { Exp. } \\
\text { Sign }\end{array}$ & Past Studies \\
\hline 1. & $\begin{array}{l}\text { Demand of IPOs } \\
\text { (DEMAND) }\end{array}$ & Subscription ratio & $+\mathrm{ve}$ & $\begin{array}{l}\text { Tajuddin et al. (2016), } \\
\text { Wan-Hussin }(2005)\end{array}$ \\
\hline 2. & $\begin{array}{l}\text { Offering } \\
\text { (OFFSIZE) }\end{array}$ & $\begin{array}{l}\operatorname{Ln}(\# \text { of total shares issued } \times \\
\text { offer price) }\end{array}$ & -ve & $\begin{array}{l}\text { Abdul-Rahim, Che-Yahya, and } \\
\text { Mohd-Rashid (2015), Song, } \\
\text { Tan, and Yi (2014) }\end{array}$ \\
\hline 3. & $\begin{array}{l}\text { Underwriter } \\
\text { Reputation } \\
\text { (UNDRANK) }\end{array}$ & $\begin{array}{l}\text { The shares underwritten for the } \\
\text { ith investment bank in the } \\
\text { listing year against the total } \\
\text { underwriting amount in ith } \\
\text { listing year }\end{array}$ & $-\mathrm{ve}$ & $\begin{array}{l}\text { Che-Yahya, Abdul-Rahim, and } \\
\text { Yong (2014), Sheela, Sanjay, } \\
\text { and Fairuz Ahmad (2017) }\end{array}$ \\
\hline 4. & $\begin{array}{l}\text { Firm } \\
\text { (COSIZE) }\end{array}$ & Ln(total assets) of ith firms & -ve & Mousa (2009), Rath (2008) \\
\hline 5. & $\begin{array}{l}\text { Market Condition } \\
\text { (MKTRETURN) }\end{array}$ & $\begin{array}{l}\text { Percentage change of FTSE } \\
\text { Bursa Malaysia KLCI index on } \\
\text { the listing day over FTSE Bursa } \\
\text { Malaysia KLCI index a year } \\
\text { before listing }\end{array}$ & $+\mathrm{ve}$ & $\begin{array}{l}\text { Mohamad, Nassir, and Ariff } \\
\text { (1994), Chong and Puah (2009) }\end{array}$ \\
\hline
\end{tabular}

Table 1. Summary of other independent variables and expected sign

Notes: +ve is the expectation on the positive relationship and -ve is the expectation on the negative relationship. 
To examine the influence of growth opportunities on the initial aftermarket performance with the controlling effect of the other five independent variables, this study used the multiple regression analysis. The equation is as follows:

$$
R_{i a}=\alpha+\beta_{1} \text { GOPP }_{i}+\beta_{2} \text { DEMAND }_{i}+\beta_{3} \text { OFFSIZE }_{i}+\beta_{4} \text { UNDRANK }_{i}+\beta_{5} \text { COSIZE }_{i}+\beta_{6} \text { MKTRETURN }_{i}+\epsilon_{i} \text { (3) }
$$

where,

\begin{tabular}{ll}
\hline$R_{i a}$ & $=$ Performance of IPO in immediate aftermarket \\
\hline$\alpha$ & $=$ The constant term \\
\hline$\beta$ & $=$ The estimate coefficient or loading of the respective factor \\
\hline GOPP $_{i}$ & $=$ Growth opportunities \\
\hline DEMAND $_{i}$ & $=$ Subscription ratio \\
\hline OFFSIZE $_{i}$ & $=$ Offering size \\
\hline UNDRANK $_{i}$ & $=$ Underwriter reputation \\
\hline COSIZE $_{i}$ & $=$ Firm size \\
\hline MKTRETURN $_{i}$ & $=$ Market Condition \\
\hline
\end{tabular}

\section{Empirical Result and Discussions}

\subsection{Descriptive Statistics Results}

Table 2 reports the descriptive statistics on 436 IPOs listed in Bursa Malaysia from January 2000 to December 2017. The mean return on the first trading day is 21.01 percent. Some investors received initial aftermarket returns as high as 409.38 percent, while some others received returns as low as -70.70 percent. The maximum value suggests that the investors earn a return of more than 400 percent even though the average returns have shown a declining value over the years. Our main variable of interest, firm's growth opportunities, shows an average of 66.11 percent, ranging from 0 to 100 percent. The result indicates that more than 65 percent of Malaysian firms went public with their primary objective to obtain funds to support for its future expansion. The remaining 33.89 percent probably went public with the objective to pay for its debt. The minimum value of 0 implies that there are IPO firms, which were not aiming to seek additional funds for growth purposes, but to fulfil the liquidity needs of their existing shareholders.

Table 2. Descriptive statistic of sample IPOs (2000-2017)

\begin{tabular}{llllll}
\hline Variables & Mean & Median & Min. & Max. & Std. Dev. \\
\hline Initial return & 21.01 & 12.67 & -70.70 & 409.38 & 45.98 \\
\hline Growth opportunities (\%) & 66.11 & 75.02 & 0.00 & 100.00 & 26.45 \\
\hline Subscription ratio (times) & 27.83 & 13.89 & -0.89 & 377.96 & 42.25 \\
\hline Offer size (RM, Millions) & 190.00 & 24.07 & 2.40 & 12500.00 & 1040.00 \\
\hline Underwriter reputation (\%) & 8.34 & 3.20 & 0.00 & 53.00 & 11.22 \\
\hline Firm Size (RM, Millions) & 503.00 & 107.00 & 0.96 & 28000.00 & 2030.00 \\
\hline Market condition (\%) & 11.56 & 10.92 & -41.24 & 96.96 & 17.84 \\
\hline
\end{tabular}

Table 3 shows the correlations among the variables. The correlation among the variables is far below the cut-off point of 0.90 (Asteriou \& Hall, 2015) except for offer size and firm size. The two variables reported the highest correlation of 0.8476 indicating that these two are highly correlated. Further, the variance inflation factor (VIF) was conducted to examine the model for multicollinearity issues. The highest value for VIF test is 4.1930 , which indicates that the value

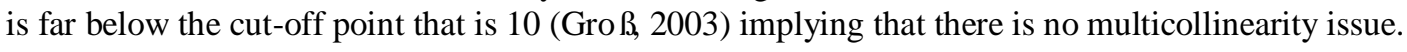


Table 3. Correlation matrix among variables

\begin{tabular}{llllllll}
\hline VARIABLES & 1 & 2 & 3 & 4 & 5 & 6 & 7 \\
\hline $\mathrm{R}_{\mathrm{ia}}$ & 1 & 0.0588 & 0.3814 & -0.1799 & 0.0280 & -0.1159 & 0.1900 \\
\hline GOPP & & 1 & 0.0551 & -0.1083 & -0.1231 & -0.2191 & -0.0355 \\
\hline DEMAND & & 1 & -0.2536 & -0.0903 & -0.2712 & 0.1890 \\
\hline OFFSIZE & & & 1 & 0.2814 & $\mathbf{0 . 8 4 7 6}$ & 0.0444 \\
\hline UNDRANK & & & & 1 & 0.2714 & 0.0955 \\
\hline COSIZE & & & & & 1 & 0.0725 \\
\hline MKTRETURN & & & & & & \\
\hline
\end{tabular}

\subsection{Main Empirical Results}

Table 4 presents and discusses the regression results. This study first conducted several diagnostic tests, which included the Jarque-Bera to test for normality of the distribution of data, White-test to test for the heterocedasticity issue, Durbin-watson for autocorrelation, and Ramsey RESET test for model specification. The reason of conducting the diagnostic test prior to its regression analysis was to ensure the cleanness of data and the reliability of results produced in this study.

As presented in Table 4, the regression models in Equation (3) reports an adjusted $\mathrm{R}^{2}$ of 17.69, indicating that 17.69 percent of variation in $\mathrm{R}_{\mathrm{ia}}$ is explained by the variables used in this study. The F-statistic of 16.58, which is significant at 99 percent level, verifies that the model is fit. There appears to be no autocorrelation issue as the Durbin Watson statistic does not exceed the established critical value and the homocedasticity issue had been solved using the Huber-white test. In general, the coefficients of all explanatory variables meet the hypothesized directions' expectations except for UNDRANK and COSIZE. Supposedly, both UNDRANK and COSIZE, and $\mathrm{R}_{\mathrm{i} a}$ were expected to be inversely related. However, the results show that both UNDRANK and COSIZE significantly and positively influence the initial aftermarket return.

The discussion now proceeds to the main result of this study that is the influence of growth opportunities of firms on the initial aftermarket performance. As mentioned in the Introduction Section, this study attempted to provide evidence on how the market reacts when the firms allocated a higher percentage of proceeds to growth activities. This study hypothesized that growth opportunities of firms should positively influence their initial aftermarket performance. Abdul-Rahim and Che-Embi (2013) state that growth opportunities signal future performance of firms to potential investors. Specifically, the higher the growth opportunities of a firm, the higher is the performance of the firm in the aftermarket. This is argued to be caused by the investors' confidence in investing in a firm, which its main aim is for expansion. Following the signaling theory, put forth in this study, firms which used their proceeds mainly for growth purposes were predicted to produce a favourable aftermarket performance. The investors, who react favourably on the information of growth opportunities of firms, will demand for the shares, which later will motivate price and return of the IPOs to be higher. Indirectly, this study is of the view that the stock market will be filled up with optimistic investors when an IPO firm allocates a higher percentage of proceeds received to growth activities.

Table 4. OLS regression results

\begin{tabular}{llll}
\hline VARIABLES & EXP. SIGN & COEFFICIENT & T-STATISTIC \\
\hline MAIN INDEPENDENT VARIABLE & & & \\
\hline GOPP & $+\mathrm{ve}$ & 0.1179 & $2.0834^{* *}$ \\
\hline OTHER INDEPENDENT VARIABLES & & & \\
\hline DEMAND & $+\mathrm{ve}$ & 0.3763 & $6.8496^{* * *}$ \\
\hline OFFSIZE & $-\mathrm{ve}$ & -10.1778 & $-3.9820^{* * *}$ \\
\hline UNDRANK & $-\mathrm{ve}$ & 0.3338 & $2.0298^{* *}$ \\
\hline COSIZE & $-\mathrm{ve}$ & 7.2157 & $2.4508^{* *}$ \\
\hline
\end{tabular}




\begin{tabular}{|c|c|c|c|}
\hline MKTRETURN & $+\mathrm{ve}$ & 0.3019 & $3.0640 * * *$ \\
\hline $\mathrm{R}^{2}$ & & 0.1883 & \\
\hline Adjusted $\mathrm{R}^{2}$ & & 0.1769 & \\
\hline F-statistic & & 16.5819 & \\
\hline p-value (F-stats) & & 0.0000 & \\
\hline Durbin Watson & & 1.6212 & \\
\hline
\end{tabular}

\begin{tabular}{ll}
\hline Ramsey TEST: & \\
\hline F-Test Statistic & 7.7132 \\
\hline p-value & 0.0057 \\
\hline
\end{tabular}

Note: Sample size $=436 . * * * * *$ and $*$ indicate significant at $1 \%, 5 \%$ and $10 \%$ level, respectively.

As presented in Table 4, GOPP is positively and significantly associated to $\mathrm{R}_{\mathrm{ia}}$. The result indicates that a return on the first trading day was higher when IPO firms allocated most of its proceeds to growth activities. The degree of relationship is significant at 5 percent level, which supports the proposition that investors react favourably and demand for the shares when IPO firms allocate a higher percentage of the proceeds from the sale of its shares to activities that possibly increase growth opportunities of the firms. From the investors' point of view, if firms allocate a higher percent of proceeds specifically to growth activities, the firms portray a clear mission on its future expansion and shows that the firms have a strong incentive to expand its business in the future. Higher growth opportunities of a firm will assist the firm to have a longer sustainability in the aftermarket, which later increases the prices and returns of the shares. The finding of this study is similar to that of Amor and Kooli (2017) that the performance of IPOs in the aftermarket is favourable when IPO firms report investment as its main intention of going-public.

Further, the finding on the influence of GOPP on $\mathrm{R}_{\mathrm{ia}}$ is consistent with both theories employed in this study (i.e., agency theory and signaling theory). The finding of this study supports the theory that the decision of a firm to allocate a higher amount of proceeds to growth activities is claimed to be consistent with the desire of the investors as it will eventually drive up the price of the share and value of their investment. As the investors' goal on value maximization is expected to be fulfilled, they should purchase shares in firms with a higher distribution of proceeds from IPOs to activities that support business expansion and growth. Hence, a positive relationship between growth opportunities of firms and immediate aftermarket return is expected as revealed in this study. Additionally, this finding supports the proposition built on the signaling theory as discussed in Section 2.2. In specific, GOPP transmits a good signal and indication to potential investors about the future performance of the firms. This signal encourages the investors to overly demand the shares, which will result in a higher price and return of IPOs in the immediate aftermarket.

The other independent variables used in this study also significantly influence the IPO initial aftermarket performance. DEMAND and MKTRETURN are significant at the 1 percent level indicating that the investors will look into the market condition before the investors make a decision to leave their money in IPOs firms. If the investors notice that the market condition is good, the investors will demand for the shares, which later boost up the share price and leads to a higher aftermarket return. Meanwhile, UNDRANK and COSIZE, which supposedly have an inverse relationship produces contradict results. It is evidenced that UNDRANK and COSIZE significantly and positively influence the initial aftermarket performance at the 5 percent level. The result indicates that the investors also consider the reputation of an underwriter prior to any investment decision. In specific, firms which engage themselves to a reputable underwriter are able to attract more investors to demand for their share as the investors believe that the underwriter will not simply underwrite firms, which are not compatible. As for COSIZE, the result suggests that a higher total asset of firms leads to a higher initial aftermarket return. Higher total assets of firms imply that the firms are stable and able to be defensive during any unfavourable event. The OFFSIZE variable is consistent with the direction hypothesized in this study. This significant negative result is consistent with the demand and supply theory in Abdul-Rahim and Che-Embi's (2013) study, which suggests that a larger offer size can easily fulfil the demand of the investors of the firm's shares during listing. 


\section{Conclusion and Recommendations}

This study examined the influence of growth opportunities of IPO firms on the initial aftermarket performance. Employing 436 IPOs listed from January 2000 to December 2017, this study found that GOPP is positively and significantly related to the $\mathrm{R}_{\mathrm{ia}}$. The significant positive results indicate that firms, which allocate a higher percentage of proceed to growth activities, are able to attract potential investors to buy shares that such attraction will encourage the IPO immediate aftermarket price and return to be higher. The reasoning of such a result in this study is due to the positive reaction of investors as they are optimistic in leaving money to IPO firms that have higher growth opportunities. Other than the GOPP, DEMAND, OFFSIZE, UNDRANK, and COSIZE, the MKTRETURN also reveals a significant influence on the immediate aftermarket performance. In summary, this study provides evidence on the other determinants of the IPO performance in the initial aftermarket. As growth opportunity of a firm was found to be one important determinant that influences the initial aftermarket performance of IPOs in the Malaysian market, the investors must consider the information on the "use of proceeds" specifically to growth activities published in the Prospectus prior to any investment decision. Nonetheless, despite the empirical evidence on the determinants of the IPO performance provided in this study, future studies are still needed to explore other possible explanation following a low adjusted $\mathrm{R}^{2}$ produced in this study. This study defines growth opportunities as the proceeds allocated to growth and investment activities only. Future studies should consider other activities stated in the "use of proceeds" section, such as marketing activities as the activities that might also motivate a higher affordability of firms to grow in the long-term aftermarket. Further, it is also recommended for future studies to extend the observation on the return in the long-term aftermarket, e.g., three years, as the influence on growth opportunity might not be totally captured in the early period after the listing, but in longer years following the issuance of IPOs in the stock market. This recommendation is practically significant to long-term investors who seek for a long-term behavior of return on shares for their capital appreciation.

Moreover, the finding of this study on the significant influence of growth opportunities of firms on the immediate aftermarket performance implies that the investors now have more indications to use prior to their investment decisions. This is by looking at information in the Prospectus that is the information in the "use of proceeds" section. Such a move will offer investors a better chance to secure high returns after selecting good IPO firms to invest and participate. Meanwhile, in order to encourage investors to invest in IPO firms as well as to help the firms to sustain longer in the aftermarket, the regulatory body, such as Securities Commission could consider imposing a recommendation to firms searching for listing in stock exchange on a reasonable value of proceeds to be allocated to growth activities as it would benefit no other than the firm itself through the increment in its price of shares in the immediate aftermarket, as evident in the finding of this study.

Lastly, future studies can also extend the scope of this study to other IPO markets since this study has provided the result that GOPP does influence the performance of the Malaysian IPOs in the initial aftermarket. In order to offer a more conclusive finding on the influence of GOPP, future studies may assess the influence of GOPP on the performance of other markets so that investors will have a wider view on the influence of GOPP in aftermarket returns.

\section{References}

Abdul-Rahim, R., \& Che-Embi, N. A. (2013). Initial returns of Shariah versus non-Shariah IPOs: Are there any differences?. Jurnal Pengurusan, 39, 37-50. https://doi.org/10.17576/pengurusan-2013-39-04

Abdul-Rahim, R., Che-Yahya, N., \& Mohd-Rashid, R. (2015). A two-dimensional approach in examining IPO behaviour in the immediate aftermarket: Malaysian evidence. https://doi.org/10.2139/ssrn.2647168

Aharony, J., Lee, C.-W. J., \& Wong, T. J. (2000). Financial packaging of IPO firms in China. Journal of Accounting Research, 38(1), 103-126. https://doi.org/10.2307/2672924

Amor, S. B., \& Kooli, M. (2017). Intended use of proceeds and post-IPO performance. The Quarterly Review of Economics and Finance, 65, 168-181. https://doi.org/10.1016/j.qref.2016.09.001

Anderloni, L., \& Tanda, A. (2017). Green energy companies: Stock performance and IPO returns. Research in International Business and Finance, 39(Part A), 546-552. https://doi.org/10.1016/j.ribaf.2016.09.016

Andriansyah, A., \& Messinis, G. (2016). Intended use of IPO proceeds and firm performance: A quantile regression approach. Pacific-Basin Finance Journal, 36, 14-30. https://doi.org/10.1016/j.pacfin.2015.12.001

Asteriou, D., \& Hall, S. G. (2015). Applied Econometrics. Location: Palgrave Macmillan. https://doi.org/10.1057/978-1-137-41547-9

Burton, B., Helliar, C., \& Power, D. (2004). The role of corporate governance in the IPO process: a note. Corporate 
governance: An International Review, 12(3), 353-360. https://doi.org/10.1111/j.1467-8683.2004.00376.x

Carey, P., Fang, V., \& Zhang, H. F. (2016). The role of optimistic news stories in IPO pricing. Journal of International Financial Markets, Institutions and Money, 41, 16-29. https://doi.org/10.1016/j.intfin.2015.12.002

Che-Yahya, N., Abdul-Rahim, R., \& Yong, O. (2014). Influence of institutional investors' participation on flipping activity of Malaysian IPOs. Economic Systems, 38(4), 470-486. https://doi.org/10.1016/j.ecosys.2014.03.002

Chong, F., \& Puah, C.-H. (2009). The Malaysian IPO market: Volume, initial returns and economic conditions. International Review of Business Research Papers, 5(5), 182-192.

Chordia, T., Roll, R., \& Subrahmanyam, A. (2001). Market liquidity and trading activity. The Journal of Finance, 56(2), 501-530. https://doi.org/10.1111/0022-1082.00335

Engelen, P.-J., \& Van Essen, M. (2010). Underpricing of IPOs: Firm-, issue- and country-specific characteristics. Journal of Banking \& Finance, 34(8), 1958-1969. https://doi.org/10.1016/j.jbankfin.2010.01.002

Espenlaub, S., Khurshed, A., \& Mohamed, A. (2012). IPO survival in a reputational market. Journal of Business Finance \& Accounting, 39(3-4), 427-463. https://doi.org/10.1111/j.1468-5957.2012.02280.x

Groß, J. (2003). Linear Regression. Germany: Springer Berlin Heidelberg. https://doi.org/10.1007/978-3-642-55864-1

Hung, M., Wong, T. J., \& Zhang, T. (2012). Political considerations in the decision of Chinese SOEs to list in Hong Kong. Journal of Accounting and Economics, 53(1), 435-449. https://doi.org/10.1016/j.jacceco.2011.10.001

Ibbotson, R. G., \& Ritter, J. R. (1995). Chapter 30 Initial public offerings. In Handbooks in Operations Research and Management Science (Vol. 9, pp. 993-1016). Elsevier. https://doi.org/10.1016/S0927-0507(05)80074-X

Jensen, M. C., \& Meckling, W. H. (1976). Theory of the firm: Managerial behavior, agency costs and ownership structure. Journal of Financial Economics, 3(4), 305-360. https://doi.org/10.1016/0304-405X(76)90026-X

Lee, C. W. J. (2001). Financial restructuring of state owned enterprises in China: The case of Shanghai Sunve Pharmaceutical Corporation. Accounting, Organizations and Society, 26(7), 673-689. https://doi.org/10.1016/S0361-3682(00)00007-6

Leone, A. J., Rock, S., \& Vasvari, F. P. (2007). Disclosure of intended use of proceeds and underpricing in initial public offerings. Journal of Accounting Research, 45(1), 111-153. https://doi.org/10.1111/j.1475-679X.2007.00229.x

Luo, Y., Qian, X., \& Ren, J. (2015). Initial public offerings and air pollution: Evidence from China. Journal of Asia Business Studies, 9(1), 99-114. https://doi.org/10.1108/JABS-08-2014-0056

Mohamad, S., Nassir, A. M., \& Ariff, M. (1994). Analysis of underpricing in the Malaysian new issues market during 1975-1990: Renew issues excessively underpriced. Capital Markets Review, 2(2), 17-27.

Mohd-Rashid, R., Abdul-Rahim, R., \& Yong, O. (2014). The influence of lock-up provisions on IPO initial returns: Evidence from an emerging market. Economic Systems, 38(4), 487-501. https://doi.org/10.1016/j.ecosys.2014.03.003

Morris, R. D. (1987). Signalling, Agency Theory and accounting policy choice. Accounting \& Business Research, 18(69), 47-56. https://doi.org/10.1080/00014788.1987.9729347

Mousa, F.-T. (2009). When do slack resources impact new venture success?. Unpublished thesis, Washington State University, Ann Arbor. Retrieved http://search.proquest.com.ezaccess.library.uitm.edu.my/docview/305018476?accountid=42518

Rath, S. (2008). The survival of initial public offerings in Australia. Paper presented at the Oxford Business \& Economics Conference Program, UK. Retrieved from http://www.gcbe.us/2008_OBEC/data/confcd.htm

Ross, S. A. (1977). The determination of financial structure: the incentive-signalling approach. The Bell Journal of Economics, 23-40. https://doi.org/10.2307/3003485

Sheela, S., Sanjay, G., \& Fairuz Ahmad, Z. (2017). Impact of investors' protection, transparency level, and legal origin on initial public offering (IPO) initial returns. Managerial Finance, 43(7), 738-760. https://doi.org/10.1108/MF-08-2016-0230

Song, S., Tan, J., \& Yi, Y. (2014). IPO initial returns in China: Underpricing or overvaluation?. China Journal of Accounting Research, 7(1), 31-49. https://doi.org/10.1016/j.cjar.2013.12.001 
Tajuddin, A. H., Abdullah, N. A. H., \& Taufil-Mohd, K. N. (2016). Does growth opportunity matter in explaining the oversubscription phenomena of Malaysian IPO?. Procedia - Social and Behavioral Sciences, 219(Supplement C), 748-754. https://doi.org/10.1016/j.sbspro.2016.05.069

Teoh, S. H., Welch, I., \& Wong, T. J. (1998). Earnings management and the long-run market performance of initial public offerings. The Journal of Finance, 53(6), 1935-1974. https://doi.org/10.1111/0022-1082.00079

Wan-Hussin, W. N. (2005). The effects of owners' participation and lockup on IPO underpricing in Malaysia. Asian Academy of Management Journal, 1(10), 19-36.

Yatim, P. (2008). Underpricing and Board Structures: An Investigation of Malaysian IPOs. Paper presented at the ECMLG2008-Proceedings of the 4th European Conference on Management Leadership and Governance: ECMLG.

\section{Copyrights}

Copyright for this article is retained by the author(s), with first publication rights granted to the journal.

This is an open-access article distributed under the terms and conditions of the Creative Commons Attribution license (http://creativecommons.org/licenses/by/4.0/). 